Reprinted with permission from: Weed Technology. 1994. 8(4):824-829.

Published and copyrighted by: Weed Science Society of America. http://www.wssa.net

\title{
Leafy spurge (Euphorbia esula) control, forage production, and economic return with fall-applied herbicides ${ }^{1}$
}

\author{
RODNEY G. LYM and CALVIN G. MESSERSMITH \\ Professors, Crop and Weed Sci. Dep., N.D. State Univ., Fargo, ND 58105.
}

\begin{abstract}
:
Leafy spurge control and forage production after various fall-applied herbicide treatment rotations were evaluated in a bluegrass pasture and a mixed grass prairie. Dicamba at $2 \mathrm{~kg}$ ae/ha or picloram at $0.6 \mathrm{~kg}$ ae/ha alone or combined with 2,4-D at $1 \mathrm{~kg}$ ae/ha applied annually for 3 years provided consistent leafy spurge control of $85 \%$ or better, but forage production was greater at the bluegrass pasture site than the mixed grass prairie site. Glyphosate plus 2,4-D at 0.4 plus $0.7 \mathrm{~kg}$ ae/ha applied annually or rotated with picloram plus $2,4-\mathrm{D}$ or dicamba provided $90 \%$ or better leafy spurge control after 3 years at the bluegrass pasture. Control was $50 \%$ or less at the mixed grass prairie site where forage production was severely reduced by glyphosate plus 2,4-D. All treatments on the bluegrass pasture provided a positive economic return averaging $\$ 227 /$ ha after 3 years. Picloram or picloram plus 2,4-D at the mixed grass prairie site provided net returns averaging $\$ 285 / \mathrm{ha}$, but treatment rotations that included glyphosate plus 2,4-D one or more times in 3 years averaged a net loss of $\$ 32 /$ ha due to severe grass injury.
\end{abstract}

\section{Nomenclature:}

Dicamba, 3,6-dichloro-2-methoxybenzoic acid; glyphosate, $N$-(phosphonomethyl)glycine; picloram, 4-amino-3,5,6-trichloro-2-pyridinecarboxylic acid; 2,4-D, (2,4-dichlorophenoxy)acetic acid; leafy spurge, Euphorbia esula L. \# EPHES, Kentucky bluegrass, Poa pratensis L.

\footnotetext{
${ }^{1}$ Received for publication April 19,1994 and in revised form August 25,1994. Published with approval of the Director, Agric. Exp. Stn., N.D. State Univ. as J. Art. No. 2190.

${ }^{2}$ Letters following this symbol are a WSSA-approved computer code from Composite List of Weeds, Revised 1989. Available from WSSA, 1508 West University Ave., Champaign, IL 61821-3133.
} 


\section{Additional index words:}

Pasture and rangeland weed control, dicamba, glyphosate, picloram, 2,4-D, EPHES.

\section{Introduction}

Leafy spurge infests approximately 840,000 ha in North Dakota, South Dakota, Montana, and Wyoming and causes an estimated total annual loss of over $\$ 110$ million $(1,9)$. Losses are due to reduced carrying capacity of infested rangeland, reduced land value, and lost business activity in these states. Also, there is an additional loss of over \$11 million annually in North Dakota alone due to reduced wildlife habitat and associated recreational activities (11).

Several long-term management alternatives provide a choice of herbicides and duration of leafy spurge control in the region. Picloram at $2.2 \mathrm{~kg} / \mathrm{ha}$ will provide greater than $90 \%$ leafy spurge control for at least two growing seasons (4). However, picloram applied at that rate is cost-prohibitive for use on large infestations $(5,6)$. When leafy spurge infests an area that can be treated annually, then dicamba at $2.2 \mathrm{~kg} / \mathrm{ha}$ or picloram plus 2,4-D at 0.3 plus $1.1 \mathrm{~kg} / \mathrm{ha}$ spring-applied will provide $85 \%$ or better leafy spurge control after 3 to 5 years. However, when these herbicides are fall applied, the picloram rate must be increased to $0.6 \mathrm{~kg} / \mathrm{ha}$ with $2,4-\mathrm{D}$ to provide similar leafy spurge control as the springapplied treatment. Thus, the fall-applied treatment is less cost-effective.

Glyphosate at $0.8 \mathrm{~kg} /$ ha fall-applied provides up to 80 to $90 \%$ leafy spurge control 12 mo after the first treatment (MAFT) ${ }^{3}$ (4). Glyphosate is nonselective so use is limited to cropland, shelterbelts, and as a spot treatment. Glyphosate applied with 2,4-D at 0.6 plus $0.4 \mathrm{~kg} / \mathrm{ha}$ in the fall provided 70 to $90 \%$ leafy spurge control and caused variable grass injury depending on location (2) and grass species (3).

Glyphosate plus 2,4-D would be a cost-effective treatment if grass injury did not reduce forage production severely. Reduction greater than $30 \%$ can lead to other perennial and annual weed invasion such as Canada thistle [Cirsium arvense (L.) Scop.] (3). Glyphosate plus $2,4-\mathrm{D}$ at 0.4 plus $0.7 \mathrm{~kg} / \mathrm{ha}$ costs approximately $70 \%$ less than the fallapplied rate of picloram plus 2,4-D at 0.6 plus $1.1 \mathrm{~kg} / \mathrm{ha}$. Some forage yield reduction by glyphosate plus 2,4-D may be acceptable to reduce long-term costs if this treatment can be alternated with other herbicides that cause negligible grass injury. The purpose of this research was to evaluate leafy spurge control, forage production, and economic return after treatment with glyphosate plus 2,4-D fall-applied annually or rotated with picloram plus 2,4-D or dicamba.

\footnotetext{
${ }^{3}$ Abbreviation: MAFT, months after the first treatment.
} 


\section{Materials and methods}

An experiment to evaluate leafy spurge control and forage production after fallapplied herbicide treatment was established at two sites in North Dakota in 1990. The sites were a bluegrass pasture near Chaffee and a mixed grass prairie (Altamont vegetation zone) on a federal game management area near Valley City. The grass species at Chaffee were mostly Kentucky bluegrass (Poa pratensis L.) with some Canada bluegrass (Poa compressa L.) and western wheatgrass (Agropyron smithii Rydb.). The main population of grasses at Valley City was western wheatgrass, intermediate wheatgrass [Elymus intermedia (Host) Nevski], crested wheatgrass (Agropyron desertorum Roemer and Schultes), smooth brome (Bromus inermis Leyss.), and big bluestem (Andropogon gerardii Vitman) with several bluegrasses. Neither area was grazed. The estimated annual vegetative production was $3530 \mathrm{~kg} / \mathrm{ha}$ for bluegrass pastures and $2630 \mathrm{~kg} / \mathrm{ha}$ for mixed grass prairie (10).

The experiment locations had at least $80 \%$ ground cover of leafy spurge and were sparsely infested with other perennial plants such as western snowberry (Symphoricarpos occidentalis Hook.), prairie wild rose (Rosa arkansana Porter), and Canada thistle. The soil at Chaffee was a Fairdale loam (fine loamy, mixed, frigid Mollie Udifluvents) with $3.8 \%$ organic matter and a $\mathrm{pH}$ of 7.8 . The soil at Valley City was a Barnes stoney loam (fine loamy, mixed, Udic Haploborolls, stoney phase) with 5\% organic matter and a $\mathrm{pH}$ of 6.3 .

Glyphosate plus 2,4-D at 0.4 plus $0.7 \mathrm{~kg} /$ ha was fall applied annually for 3 years in the same plots or alternated with other herbicide treatments selected on cost and efficacy of leafy spurge control as determined from previous research $(4,6)$. These treatments included picloram at $0.6 \mathrm{~kg} / \mathrm{ha}$ applied alone or with 2,4-D at $1 \mathrm{~kg} / \mathrm{ha}$, picloram plus 2,4-D at 0.3 plus $1 \mathrm{~kg} / \mathrm{ha}$, and dicamba at $2.2 \mathrm{~kg} / \mathrm{ha}$. Initial treatments were applied Sept. 19, 1990, when leafy spurge was in the fall-regrowth stage, and subsequent treatments were applied in mid-September in 1991 and 1992 when leafy spurge was in the vegetative to flowering stage. Although leafy spurge generally flowers in mid-June, this growth stage was delayed in 1991 and 1992 due to the herbicide treatments fall-applied the previous year(s).

Herbicides were applied without an adjuvant using a tractor-mounted sprayer delivering $80 \mathrm{~L} / \mathrm{ha}$ at $240 \mathrm{kPa}$. Plots were 3.1 by $9.1 \mathrm{~m}$, and each treatment was replicated four times in a randomized complete block design. Leafy spurge control and grass stand reduction were estimated visually as compared with the untreated control in May each year. Forage production and leafy spurge biomass were determined in July 1991 through 1993 by clipping three $0.25-\mathrm{m}^{2}$ quadrats per plot and separating into leafy spurge and forage components. The samples were dried at $60^{\circ} \mathrm{C}$ for 72 hours, and yields are reported with $12 \%$ moisture content. The entire plot was mowed after harvest each year and residue removed to maintain plot uniformity.

Economic data were estimated by converting forage production to grass hay sold for $\$ 64 / \mathrm{t}$ [the 5-year average price (7)] minus the application cost (estimated at $\$ 5 / \mathrm{ha}$ ) and herbicide costs. The average herbicide costs during the experiment were 2,4-D alkanola-

mine at $\$ 5.25 / \mathrm{kg}$, dicamba at $\$ 35.50 / \mathrm{kg}$, picloram at $\$ 90 / \mathrm{kg}$, and the commercial mixture

Page 3 of 8 
of glyphosate plus $2,4-\mathrm{D}^{4}$ at $\$ 17.60 / \mathrm{kg}$ (144 g glyphosate isopropylamine plus $227 \mathrm{~g} 2,4-$ $\mathrm{D}$ isopropylamine/L).

Total net return was not calculated for the control treatment (Table 1), because these experimental areas were so heavily infested with leafy spurge that farmers likely would not purchase hay from these sites. Leafy spurge on the treated plots was delayed in development, so seed was not being produced at hay harvest. Thus, farmers could purchase this hay but would not pay the same price as pure hay, so income was calculated on the basis of grass forage production without any credit for the leafy spurge component of hay. Data for all evaluations were analyzed using the general linear models procedure with the protected LSD mean separation technique (8). Results differed by location and are reported separately. However, variance across the years was similar at a particular location so the combined data are presented. Harvest by year data were pooled for illustrative purposes and compared glyphosate plus 2,4-D applied for 3 years consecutively to treatments that contained glyphosate plus 2,4-D in years 1 and 3 (two-year total), year 2 only (four-year total), or none (four-year total).

\section{Results and discussion}

All treatments controlled leafy spurge topgrowth in the fall following application (data not shown) and control and forage production in the bluegrass pasture site were satisfactory from three annual fall-applied treatments regardless of herbicide (Table 1). However, leafy spurge control by treatment varied greatly at the mixed grass prairie site. Treatments with picloram, picloram plus 2,4-D, or dicamba applied all 3 years provided the most consistent leafy spurge control regardless of location, but forage production varied dramatically between locations. Herbicide rotations that included glyphosate resulted in much less forage production compared with the untreated control at the mixed grass prairie site than at the bluegrass pasture site.

Most herbicide rotations at the bluegrass pasture site provided $80 \%$ or more leafy spurge control 30 MAFT; the exceptions were two treatments that contained picloram plus 2,4-D at 0.3 plus $1 \mathrm{~kg} /$ ha which only averaged $75 \%$ leafy spurge control (Table 1 ). The greatest reductions in leafy spurge biomass at the bluegrass pasture site occurred with glyphosate plus 2,4-D rotated with dicamba the second year and with picloram plus 2,4-D at 0.6 plus $1 \mathrm{~kg} / \mathrm{ha}$ applied all 3 years which averaged $680 \mathrm{~kg} / \mathrm{ha}$ or $29 \%$ of the control.

Leafy spurge control at the mixed grass prairie site generally was much lower than at the bluegrass pasture site (Table 1). The only treatments that provided $85 \%$ or better leafy spurge control after three consecutive treatments were picloram applied alone or with 2,4-D, and dicamba at $2.2 \mathrm{~kg} / \mathrm{ha}$. However, leafy spurge biomass production with these four treatments still averaged $2150 \mathrm{~kg} / \mathrm{ha}$ or $46 \%$ of the control.

\footnotetext{
${ }^{4}$ Landmaster BW. Monsanto Company, St. Louis, MO 63167.
} 
Table 1. Leafy spurge control and biomass, forage yield, and net return after 3 years of fall-applied treatments on a bluegrass pasture site and mixed grass prairie site in North Dakota.

\begin{tabular}{|c|c|c|c|c|c|c|c|c|c|c|}
\hline \multirow{2}{*}{\multicolumn{2}{|c|}{1990 and 1992 treatment }} & \multirow{2}{*}{\multicolumn{2}{|c|}{1991 treatment }} & \multirow{3}{*}{$\begin{array}{l}\text { 3-year total } \\
\text { cost }\end{array}$} & \multirow{2}{*}{\multicolumn{3}{|c|}{ Months after first treatment ${ }^{\mathrm{a}}$}} & \multicolumn{3}{|c|}{3 -year total } \\
\hline & & & & & & & & \multicolumn{2}{|c|}{ Production } & \multirow[b]{2}{*}{ Net return ${ }^{\mathrm{b}}$} \\
\hline \multirow[t]{3}{*}{ Herbicide } & Rate & Herbicide & Rate & & 9 & 21 & 30 & Forage & $\overline{\text { Leafy spurge }}$ & \\
\hline & $\mathrm{kg} / \mathrm{ha}$ & & $\mathrm{kg} / \mathrm{ha}$ & $\$ /$ ha & 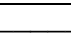 & contr & 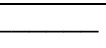 & 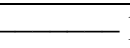 & /ha & \$/ha \\
\hline & & & & & & & ass past & - & & \\
\hline Glyphosate + 2,4-D & $0.4+0.7$ & Glyphosate $+2,4-\mathrm{D}$ & $0.4+0.7$ & 75 & 75 & 95 & 90 & 3460 & 1360 & 202 \\
\hline Glyphosate $+2,4-\mathrm{D}$ & $0.4+0.7$ & Picloram $+2,4-\mathrm{D}$ & $0.6+1$ & 115 & 65 & 85 & 90 & 3880 & 1690 & 198 \\
\hline Glyphosate + 2.4-D & $0.4+0.7$ & Dicamba & 2.2 & 140 & 70 & 90 & 95 & 4330 & 850 & 206 \\
\hline Picloram + 2,4-D & $0.6+1$ & Glyphosate $+2,4-\mathrm{D}$ & $0.4+0.7$ & 150 & 70 & 85 & 95 & 4560 & 1070 & 214 \\
\hline Picloram + 2,4-D & $0.6+1$ & Picloram $+2,4-\mathrm{D}$ & $0.6+1$ & 190 & 75 & 90 & 95 & 5270 & 520 & 234 \\
\hline Picloram + 2,4-D & $0.3+1$ & Glyphosate $+2,4-\mathrm{D}$ & $0.4+0.7$ & 100 & 50 & 75 & 80 & 5200 & 1660 & 317 \\
\hline Picloram + 2,4-D & $03+1$ & Picloram + 2,4-D & $0.3+1$ & 110 & 40 & 75 & 80 & 4550 & 2270 & 252 \\
\hline Picloram & 0.6 & Glyphosate $+2,4-\mathrm{D}$ & $0.4+0.7$ & 140 & 55 & 85 & 85 & 5700 & 1860 & 318 \\
\hline Picloram & 0.6 & Picloram & 0.6 & 170 & 60 & 90 & 95 & 5570 & 1500 & 276 \\
\hline Dicamba & 2.2 & Glyphosate $+2,4-\mathrm{D}$ & $0.4+0.7$ & 210 & 70 & 80 & 85 & 4370 & 2170 & 143 \\
\hline Dicamba & 2.2 & Dicamba & 2.2 & 275 & 65 & 85 & 95 & 5130 & 1410 & 137 \\
\hline Control & - & & - & 0 & 0 & 0 & 0 & 4860 & 2370 & \\
\hline $\operatorname{LSD}(0.05)$ & & & & & 24 & 12 & 13 & NS & 710 & 58 \\
\hline Glyphosate $+2,4-\mathrm{D}$ & $0.4+0.7$ & Glyphosate $+2,4-\mathrm{D}$ & $0.4+0.7$ & 75 & 60 & 5 & 20 & 300 & 5110 & $(51)$ \\
\hline Glyphosate $+2,4-\mathrm{D}$ & $0.4+0.7$ & Picloram $+2,4-\mathrm{D}$ & $0.6+1$ & 115 & 65 & 90 & 50 & 1310 & 3550 & $(8)$ \\
\hline Glyphosate $+2,4-\mathrm{D}$ & $0.4+0.7$ & Dicamba & 2.2 & 140 & 70 & 55 & 35 & 920 & 3600 & (68) \\
\hline Picloram + 2,4-D & $0.6+1$ & Glyphosate + 2,4-D & $0.4+0.7$ & 150 & 90 & 40 & 75 & 2160 & 3680 & 22 \\
\hline Picloram + 2,4-D & $0.6+1$ & Picloram + 2,4-D & $0.6+1$ & 190 & 95 & 95 & 95 & 6200 & 1410 & 309 \\
\hline Picloram $+2,4-\mathrm{D}$ & $0.3+1$ & Glyphosate + 2,4-D & $0.4+0.7$ & 100 & 80 & 15 & 55 & 1550 & 4790 & 24 \\
\hline Picloram + 2,4-D & $0.3+1$ & Picloram + 2,4-D & $0.3+1$ & 110 & 75 & 70 & 85 & 4060 & 2960 & 214 \\
\hline Picloram & 0.6 & Glyphosate $+2,4-\mathrm{D}$ & $0.4+0.7$ & 140 & 95 & 15 & 80 & 1720 & 2690 & 0 \\
\hline Picloram & 0.6 & Picloram & 0.6 & 170 & 90 & 90 & 95 & 6280 & 1600 & 333 \\
\hline Dicamba & 2.2 & Glyphosate $+2,4-\mathrm{D}$ & $0.4+0.7$ & 210 & 75 & 10 & 40 & 790 & 4210 & (144) \\
\hline Dicamba & 2.2 & Dicamba & 2.2 & 275 & 80 & 70 & 85 & 4550 & 2610 & 90 \\
\hline Control & - & & - & 0 & 0 & 0 & 0 & 3420 & 4650 & \\
\hline $\operatorname{LSD}(0.05)$ & & & & & 13 & 22 & 20 & 2140 & 1650 & 57 \\
\hline
\end{tabular}

${ }^{\mathrm{a}}$ First treatment in 1990.

${ }^{\mathrm{b}}$ Numbers in ( ) mean net loss.

Page 5 of 8 
Differences in leafy spurge control at the two sites apparently were not attributable to physiographic differences. Precipitation at both locations averaged $570 \mathrm{~mm} /$ year, which was about $15 \%$ above average. Slight differences in soil properties like $\mathrm{pH}$ and organic matter content should not affect efficacy of the herbicides applied postemergence in this experiment. However, there apparently were two reasons why leafy spurge was controlled better at the bluegrass pasture site than the mixed grass prairie site.

First, glyphosate plus 2,4-D provided much better leafy spurge control at the bluegrass pasture site compared to the mixed grass prairie site (Table 1). Control with glyphosate plus 2,4-D 9 MAFT, averaged across all treatments, was nearly identical at $70 \%$ at the bluegrass pasture site and $65 \%$ in the mixed grass prairie site. However, leafy spurge control the following season (21 MAFT) dropped dramatically at the prairie but not at the bluegrass pasture site. Thus, glyphosate plus 2,4-D applied 3 years consecutively provided $90 \%$ leafy spurge control at the bluegrass pasture but only $20 \%$ at the mixed grass prairie site. Leafy spurge control steadily increased each year for each treatment at the bluegrass pasture site but declined dramatically whenever glyphosate plus 2,4-D was included in the rotation at the mixed grass prairie site. For example, leafy spurge control 9,21, and 30 MAFT from dicamba applied in years 1 and 3 with glyphosate plus 2,4-D in year 2 averaged 70, 80 and $85 \%$ control, respectively, at the bluegrass pasture site versus 75,10 , and $40 \%$, control, respectively, at the mixed grass prairie site.

Second, grass provided less competition in the mixed grass prairie site than the bluegrass pasture site. Total vegetation (forage plus leafy spurge biomass) for the untreated control after three growing seasons was similar at $7230 \mathrm{~kg} / \mathrm{ha}$ for the bluegrass pasture site and $8070 \mathrm{~kg} / \mathrm{ha}$ for the mixed grass prairie site (Table 1). However, total forage production in the untreated control was $4860 \mathrm{~kg} / \mathrm{ha}$ at the bluegrass pasture site but only $3420 \mathrm{~kg} / \mathrm{ha}$ in the mixed grass prairie site. Concurrently, total leafy spurge biomass was 2370 and $4650 \mathrm{~kg} / \mathrm{ha}$ in the pasture and prairie locations, respectively. Thus, leafy spurge averaged $33 \%$ of the total production at the bluegrass pasture site but $57 \%$ at the mixed grass prairie site.

In addition to total forage yield being low as a proportion of total vegetation on the mixed grass prairie, grass injury was much more severe at the prairie than the pasture location (Table 1). Specifically, glyphosate plus 2,4-D fall-applied tended to reduce forage production during the next growing season compared to the untreated control and the broadleaf herbicide treatments at both locations (Figure 1). At both locations, forage production gradually increased each year when a broadleaf herbicide was applied in the year before harvest and generally declined the year after glyphosate plus 2,4-D was applied in the rotation.

Page 6 of 8 

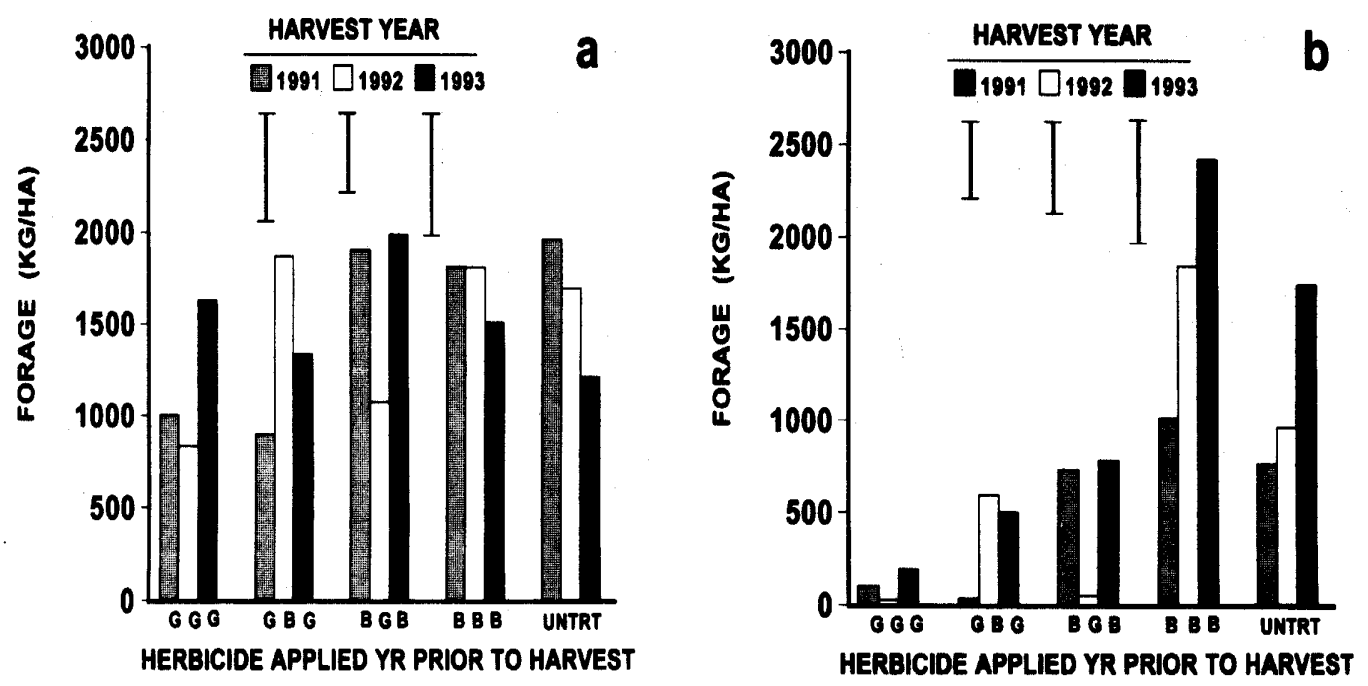

Figure 1. Forage production (a) on a bluegrass pasture site and (b) on mixed grass prairie site for the growing season after a fall-applied treatment of either glyphosate plus 2,4-D (G) or a broadleaf herbicide $(B=$ picloram, picloram plus $2,4-\mathrm{D}$, or dicamba). UNTRT $=\mathrm{Un}$ treated control.

The effect of glyphosate on natural and introduced grasses is species dependent (3). Western wheatgrass production after fall-applied glyphosate was $20 \%$ of the untreated control and decreased more than any other species in a native rangeland trial in North Dakota. Also, intermediate wheatgrass produced only $60 \%$ of the untreated control following glyphosate treatment in seeded plots. Western and intermediate wheatgrass were major species at the mixed grass prairie site, so some grass injury was expected. However, the nearly total loss of grass production at the mixed grass prairie site following the first glyphosate plus 2,4-D treatment was unexpected (Figure 1). The reason for the high grass injury at the mixed grass prairie site is not known. At the beginning of the study injury from glyphosate plus 2,4-D was expected to be highest at the bluegrass pasture site, but the opposite occurred. However, injury may have been minimized in this study because the treatments were fall-applied when bluegrass was dormant or growing slowly. Also, even though precipitation amounts were similar at the two locations, the stoney loam soil tended to dry faster following a rainfall at the mixed grass prairie site than the loam soil at the bluegrass pasture site. The additional stress may have contributed to the increased grass injury from glyphosate at the mixed grass prairie compared to the bluegrass pasture site.

All treatments at the bluegrass pasture provided a positive economic return for hay averaging $\$ 227 /$ ha after 3 years (Table 1). The greatest net return, averaging $\$ 318 /$ ha, occurred when picloram at $0.6 \mathrm{~kg} /$ ha or picloram plus $2,4-\mathrm{D}$ at 0.3 plus $1 \mathrm{~kg} / \mathrm{ha}$ was applied in the first and third year with glyphosate plus 2,4-D applied in the second year. However, these treatments averaged only $83 \%$ leafy spurge control 30 MAFT compared to $95 \%$ control achieved by five other treatments. Of the treatments that provided the bestcontrol, an annual treatment of picloram plus 2,4-D at 0.6 plus $1 \mathrm{~kg} / \mathrm{ha}$ was the most costeffective considering both leafy spurge and forage production. This treatment resulted in a net return of $\$ 234 / \mathrm{ha}$, and the $520 \mathrm{~kg} /$ ha leafy spurge biomass was just $9 \%$ of the total 
harvested yield. Treatments that included dicamba tended to be the least cost-effective because of the higher cost of dicamba at $2.2 \mathrm{~kg} / \mathrm{ha}$ compared to picloram at $0.6 \mathrm{~kg} / \mathrm{ha}$ or less, and glyphosate at $0.4 \mathrm{~kg} / \mathrm{ha}$.

Several treatments at the mixed grass prairie site provided a positive economic return (Table 1). Picloram or picloram plus 2,4-D applied all 3 years provided average net return of $\$ 285 / \mathrm{ha}$, but treatments that included glyphosate plus $2,4-\mathrm{D}$ one or more times in 3 years averaged a net loss of $\$ 32 /$ ha because of the severe grass injury (Table 1). Picloram at $0.6 \mathrm{~kg} / \mathrm{ha}$ applied alone or with $2,4-\mathrm{D}$ was the most cost-effective treatment and resulted in an average net return of $\$ 321 /$ ha and $1510 \mathrm{~kg} / \mathrm{ha}$ leafy spurge biomass or $19 \%$ of the total harvested yield. Both treatments provided $95 \%$ leafy spurge control when evaluated in late May, which was 6 to 7 weeks before forage harvest. Dicamba at $2.2 \mathrm{~kg} / \mathrm{ha}$ applied 3 years consecutively averaged $85 \%$ leafy spurge control but only returned $\$ 90 /$ ha. Dicamba applied in years 1 and 3 with glyphosate plus 2,4-D in year 2 averaged $40 \%$ control with a net loss of $\$ 144 /$ ha.

Glyphosate plus 2,4-D provided 90\% leafy spurge control 30 MAFT at the bluegrass pasture site but only $20 \%$ at the mixed grass prairie site where forage production was severely reduced. Glyphosate plus 2,4-D applied for leafy spurge control in pasture and rangeland may cause grass injury ranging from minor to severe depending on grass species and growing conditions. Glyphosate plus 2,4-D could be used in a-long-term management program as the first-year treatment, especially to control dense infestations of leafy spurge where grass production is already greatly reduced. The cost savings for glyphosate plus 2,4-D compared to picloram plus 2,4-D would more than offset lost forage production the first year. Retreatments the following year could include picloram plus 2,4-D or dicamba but not glyphosate to avoid grass injury.

\section{Literature cited}

1. Bangsund, D. A. and F. L. Leistritz. 1991. Economic impact of leafy spurge in Montana, South Dakota, and Wyoming. Agric. Econ. Rep. 275. North Dakota State Univ., Fargo, 58105.

2. Lym, R. G., K. G. Beck, P. K. Fay, M. Ferrell, and M. Peterson. 1991. Leafy spurge control with glyphosate plus 2,4-D: A regional research project. Proc. West. Soc. Weed Sci. 44:33-35.

3. Lym, R. G. and D. R. Kirby. 1991. Effect of glyphosate on introduced and native grasses. Weed Technol. 5:421-425.

4. Lym, R. G. and C. G. Messersmith. 1985. Leafy spurge control with herbicides in North Dakota: 20-year summary. J. Range Manage. 38:149-154.

5. Lym, R. G. and C. G. Messersmith. 1985. Leafy spurge control and improved forage production with herbicides. J. Range Manage. 38:386-391.

6. Lym, R. G. and C. G. Messersmith. 1990. Cost-effective long-term leafy spurge control with herbicides. Weed Technol. 4:635-641.

7. N.D. Agric. Statistics Serv. 1992. North Dakota Agricultural Statistics. No. 61. Fargo, ND 58108-3166.

8. Statistical Analysis System Institute. 1990. SAS/STAT User’s Guide: Statistics. Cary, NC.

9. Thompson, F., J. A. Leitch, and F. L. Leistritz. 1990. Economic impact of leafy spurge in North Dakota. North Dakota Farm Res. 47(6):9-11.

10. U.S. Soil Conservation Service. 1984. Technical Guide. Notice ND-35. Bismarck, ND.

11. Wallace, N. M., J. A. Leitch, and F. L. Leistritz. 1992. Economic impact of leafy spurge on North Dakota wildland. North Dakota Farm Res. 49(5):9-13.

Page 8 of 8 